\title{
THE CORRELATION BETWEEN COGNITIVE TEST-TAKING STRATEGIES AND ACHIEVEMENT IN TOEFL READING COMPREHENSION OF THE STUDENTS OF ENGLISH DEPARTMENT AT STATE UNIVERSITY OF MAKASSAR \\ Korelasi Antara Strategi Kognitif Test-Taking dan Pencapaian dalam Pemahaman Membaca TOEFL dari Mahasiswa Pendidikan Bahasa Inggris pada Universitas Negeri Makassar
}

\author{
Sukmawati \\ STIKES Mega Rezky Makassar \\ sukmar.dilla@gmail.com
}

\begin{abstract}
This study investigated the correlation between cognitive test-taking strategies and achievement in TOEFL reading comprehension. It was conducted to find out: (1) the most dominant cognitive test-taking strategy applied by the students of English Department at the State University of Makassar, (2) the TOEFL reading achievement of the students of English Department at the State University of Makassar, (3) the correlation between students' cognitive test-taking strategies and their achievement in TOEFL reading comprehension. The research applied correlation research design. This research was conducted to the fourth-semester students in three fields of study at English Department of the State University of Makassar. There were 20 students were from English Education, 12 students from English Literature and 15 students from Business English. The data were collected through documentation of TOEFL reading comprehension score and questionnaire. The research result showed that (1) comprehending strategy was the most dominant cognitive test-taking strategy applied by the students of English Department at the State University of Makassar, (2) the TOEFL reading achievement was achieved into the fair category. It was proven by mean score 42.51 range from 21-30 score. (3) There was a correlation between cognitive test-taking strategies and TOEFL reading achievement with $r=.822$ classified as a high category in which score interval was higher than 66. Therefore, cognitive test-taking strategies have a role toward TOEFL reading achievement.

Keywords: Cognitive Test-Taking Strategies, TOEFL Reading Comprehension, Correlating Strategies and Achievement.
\end{abstract}

Reading is conducted for many purposes. People read newspapers to get information about advertisements, politics, or hot news. People read novels for entertainment so that they sometimes create their imagination to keep the story alive. For the academic reason, students are asked to read materials to extend their knowledge or certain topics based on each field of study. The key of reading is comprehension (Tankersley, 2003:90). Reading comprehension is dependent on three factors. The first factor is that the reader has knowledge about structures of the text. The second one is that the reader is able to monitor and reflect on his or her own level of understanding while reading the material. The last one is that the 
reader has an adequate background in the content and vocabulary being presented. In other words, those factors are basic in learning reading comprehension.

To measure the extent to which students' ability in reading comprehension, the teacher administers a test. Bachman (1990) states that tests are designed to obtain a sample of individual behavior. In other words, tests can measure students' ability whether or not they can pass the learning based on their score. The teacher often gives the objective test to students, such as multiple-choice test.

The test is not only conducted in the educational area but also in other areas. According to Mohammadi \& Abidin (2011:237), the test has enlarged beyond the schools as a serious decision. It is conducted for college admission, certification or personal selection. A test commonly used to measure the extent to which ability in English is a test of English as a foreign language (TOEFL). Many people take TOEFL test to continue study either in their country or another country. In addition, TOEFL test is conducted to get a better job. In this regard, TOEFL test becomes a global test in worldwide.

TOEFL test is a compulsory test for students in English Department. It consists of three sections including listening section, structure and written section and reading comprehension section. However, the researcher limits her study only on reading comprehension section regarding with this research. In taking this section, students often feel that the section is difficult in which there are many unfamiliar words for them. Besides, the texts are boring because of its length. This section is also placed in the last section so that students are too tiring to think. Others sometimes underestimate it since the answers were provided in the text itself. Consequently, many students get a low score in reading comprehension section. Those problems happen because students do not learn the strategies applied in taking TOEFL reading comprehension test.

There are many strategies used in taking TOEFL reading comprehension test. Some strategies are similar to reading comprehension strategies taught in the classroom regularly, but there are also strategies that are not used especially in paper-based TOEFL. They are summarizing, making prediction and paraphrasing. The test takers can apply strategies such as scanning, skimming, identifying the 
main idea, making a prediction, making an inference or guessing the word by using the context clues in the text.

As the purpose of the study, the researcher explored students of English Department at CLS. Therefore, the researcher formulated research questions as follows:

1. What cognitive test-taking strategy is the most dominant applied by students of English Department at the State University of Makassar?

2. What is the TOEFL reading achievement of students of English Department at the State University of Makassar?

3. Is there any significant correlation between students' cognitive test-taking strategies and their achievement in TOEFL reading comprehension?

\section{Review of Related Literature}

Many researchers had investigated the correlation between test-taking strategies and students' performance on test-taking strategies. Zhang et.al (2013) investigated kinds of test-taking strategies use. They found that compensation strategies were mostly used by students and there were twenty-one strategy items of metacognitive strategies that significantly correlated with students' test performance. Sathopoulou \& Nikaki (2009) found the most popular cognitive strategies used by students of Greek were inferring meaning, using prior knowledge to deal with the topic and searching for specific information. They also found that metacognitive strategies, such as considering the type of text and its characteristics (i.e. length, organization, and other text features).

Ghafournia \& Afgari (2013) had investigated the correlation between cognitive test-taking strategies and reading comprehension. They found comprehending and retrieval strategies more frequently at the high level of reading proficiency than the participants at the intermediate and low levels. This study is supported by Bachman and Palmer's (2010) idea about the interaction between the two sets of linguistic and non-linguistic factors (i.e., English reading comprehension as part of linguistic factor and strategies as part of non-linguistic factor).

In Indonesia, especially in Makassar, the research of cognitive test-taking strategies is a new research. This research describes strategies used by test-takers' 
based on the category of cognitive strategies in answering TOEFL reading comprehension. Cognitive strategies are ongoing mental activities used by testtakers to utilize their world knowledge and language to solve the given task (Zareee 2007).

According to Purpura (1999), cognitive processing is a multi-dimensional construct constituting a set of comprehending, memory and retrieval strategies. Related to Purpura's idea, Phakiti (2006) states the examples of comprehending strategies including identifying main ideas, making inference about implied meaning, skimming, scanning and making a prediction. The examples of memory strategies are making a conclusion, using picture, rereading, underlining and note taking. Nevertheless, the researcher used making conclusion adjusted TOEFL reading comprehension. The examples of retrieval strategies are finding pronoun referent and determining words meanings. These strategies classification are used as part of cognitive test-taking strategies.

TOEFL reading comprehension had been investigated by Freedle \& Kostin's idea in Anderson, (2001:88). They found that there was 58\% of the variance in item difficulty in TOEFL such as sentence length; passage length; paragraph length; rhetorical organization.

In test-taking settings, cognitive strategies enable test takers to use their linguistic and world knowledge to solve given tasks. It means that test takers employ their language ability and prior knowledge in doing given task. Good examples of cognitive strategies used for taking reading tests are making prediction, translating, summarizing, linking to prior knowledge or experience, applying grammatical rules, and guessing meaning from contexts ( $\mathrm{O}^{\prime}$ Malley \& Chamot, 1990; Oxford, 1990)

Regarding the study, the researcher adopts cognitive strategies in taking reading comprehension test from Phakiti (2006). Cognitive strategies include comprehending, memory and retrieval strategies. The examples of cognitive strategies are adapted from Phillips (2001).

1) Comprehending strategies are used by language learners to comprehend text and extract meaning. The examples of comprehending strategies are:

a). Identify main idea, topic, and title. The answer to these questions can 
generally be determined by using the following steps: (i) read the first line of each paragraph; (ii) look for an idea in the first line; (iii) pass your eyes quickly over the rest of the passage to check that the examinees really have found the main point.

b). Make an inference about the implied meaning. There are two types of indirectly answered questions, namely (1) implied detail questions - the examinees are asked to find out some information that given in the passage, (2) Unstated details - (i) choose a key word in the question; (ii) find the keyword (or related idea) in the passage; (iii) read sentence that contains the key word or idea carefully; (iv) look for the answers that are definitely true according to the passage; (v) choose the answer that is not true or not discussed in the passage.

c). Skim reading texts. There are two types of questions at this point, namely (1)stated detail question - (i) choose key word in the question;(ii) skim in the appropriate part of the passage for the key word or idea;(iii) read sentence that contains the key word or idea carefully; (iv) look for the answer that restates an idea in the passage, and determine the tone, (2)determine - (i) skim the passage looking for clues that author is showing some emotion; (ii) choose the answer that identifies the emotion.

d). Scan reading texts. (i) Choose the key word or idea in the question; (ii) scan the lines in the passage that are listed in the answers to the question; (iii) choose the answer that contains the line numbers of a restatement of the question.

e). Making prediction. (i) Read the first line for preceding question; (ii) read the last line for the following question; (iii) determine what comes before or after; (iv) choose the answer that is reflected in the first or last line of the passage.

2). Memory strategies

a). Make a conclusion. The examinees can draw a conclusion about the author's purpose by referring to the main idea and the organization of details in the passage.

b). Elimination. The examinees read questions then find answers by 
eliminating the wrong answers.

3). Retrieval strategies

a). Find pronoun referents (i) find the pronoun in the passage. (The line where the pronoun can be found is generally stated in the question); (ii) look for nouns that come before the pronoun; (iii) read the part of the passage before the pronoun carefully.

b).Find definition from structural clues. The examinees should retrieve types of clues, including (1) punctuation: comma, parentheses, and dashes; (2) restatement: or, that, is, in order words, i.e; (3) example: such as, for example, e.g. The answer to this question can generally be using the following steps: (i) find the word in the passage; locate any structural clues; (ii) read the part of the passage after the structural clue carefully.

c). Determine meaning from word parts. The examinees can learn word parts such as bi- means two. Thus, bidirectional means in two or both direction.

Based on examples of cognitive test-taking strategies above, the researcher concludes that Cognitive Test-Taking Strategies in this research are strategies used by students in taking TOEFL reading comprehension section, based on the category of cognitive strategy. The focus of cognitive strategies in this research consists of comprehending, memory and retrieval strategies. Comprehending strategies are strategies that used to comprehend ideas in the reading passage; Memory strategies are strategies that used to remember ideas of reading passage; Retrieval strategies are strategies that used to remember vocabularies and pronouns related to reading the passage.

\section{METHOD}

\section{Participants}

The researcher took a sample from students who enroll ELTIC course at Center for Language Service (CLS) of State University of Makassar. There were 20 students from English Education, 12 students from English Literature and 15 students from Business English. 


\section{Instruments}

The researcher used documentation of TOEFL reading comprehension score and questionnaire. Documentation of TOEFL reading comprehension score was used to find out students' achievement during taking ELTIC course. Meanwhile, a questionnaire was used to measure cognitive test-taking strategies applied by the students.

a. Documentation of TOEFL Reading Comprehension Score

The documentation of TOEFL reading comprehension scores used to find out the students' achievement during taking ELTIC course which was provided by CLS. The section consisted of five reading comprehension passage, followed by 50 multiple-choice items.

b. Questionnaire

The researcher used a questionnaire that described cognitive test-taking strategies. She used a 5-point Likert scale to indicate the frequency of using each strategy applied by students. This questionnaire consisted of 30 statements. It was piloted to the students who had passed ELTIC course. The result of validation showed that 10 statements were invalid and 20 statements were valid In addition, the reliability analysis was conducted. It was calculated by using Cronbach's alpha formula. The reliability index was $(\mathrm{r}=8.48)$ which was highly reliable.

\section{Procedures}

The students were given TOEFL test by CLS. The time allotted to answer the test was 120 minutes. By assessing TOEFL reading comprehension, the researcher took the only score of TOEFL reading comprehension section at CLS. Then, the researcher gave the questionnaire to students after TOEFL test took place. The time allotted to answer the questionnaire was 15 minutes.

\section{Data Analysis}

The researcher used descriptive statistics and inferential statistics, Pearson Product Moment, through using the $20^{\text {th }}$ version of SPSS software.

\section{RESULTS AND DISCUSSION}

The findings of this study are described and discussed in the following three research questions. 
4.1 What cognitive test-taking strategy is the most dominant applied by students of English Department at the State University of Makassar?

To investigate the first research question, the descriptive statistics were calculated. The results can be seen in Table 1 .

Table 1. Mean Score and Standard Deviations of Cognitive Test-Taking of Students' English Education, English Literature and Business English

\begin{tabular}{lcccccc}
\hline \multirow{2}{*}{ Field of study } & \multicolumn{2}{c}{ Comprehending } & & \multicolumn{2}{c}{ Retrieval } \\
& Strategies & \multicolumn{2}{c}{ Memory Strategies } & \multicolumn{2}{c}{ Strategies } \\
\cline { 2 - 7 } & Mean & SD & Mean & SD & Mean & SD \\
\hline Eng. Education & 29.25 & 2.97 & 23.95 & 3.03 & 22.30 & 3.70 \\
Eng. Literature & 28.58 & 4.17 & 22.17 & 4.02 & 20.92 & 2.68 \\
Buss. English & 26.40 & 4.58 & 21.93 & 2.55 & 20.86 & 3.50 \\
\hline Average & 28.08 & 3.91 & 22.68 & 3.20 & 21.38 & 3.30 \\
\hline
\end{tabular}

As shown in Table 1, students of English Education applied comprehending strategies $(M=29.25, S D=2.97)$, followed by memory strategies $(M=23.95$, $\mathrm{SD}=3.03)$, while retrieval strategies $(\mathrm{M}=22.30, \mathrm{SD}=3.70)$. In addition, students of English Literature applied comprehending strategies $(\mathrm{M}=28.58, \mathrm{SD}=4.17)$, followed by memory strategies $(\mathrm{M}=22.17, \mathrm{SD}=4.02)$, while retrieval strategies $(\mathrm{M}=20.92, \mathrm{SD}=2.68)$. Then, students of Business English applied comprehending strategies $(M=26.40, S D=4.58)$, followed by memory strategies $(M=21.93$, $\mathrm{SD}=2.55)$, while retrieval strategies $(\mathrm{M}=20.86, \mathrm{SD}=3.50)$.

4.2 What is the TOEFL reading achievement of students of English Department at the State University of Makassar?

Table 2 Mean Score and Standard Deviation of TOEFL Reading Achievement of English Education, English Literature, and Business English.

\begin{tabular}{|ccc|}
\hline Field of Study & Mean Score & Standard Deviation \\
English Education & 43.40 & 4.83 \\
English Literature & 42.25 & 4.61 \\
Business English & 41.87 & 5.73 \\
Average & 42.51 & 5.06 \\
\hline
\end{tabular}


As shown in Table 2, the mean score of the three study fields was described fair category (42.51). While standard deviation was 5.06 indicating there were many variation scores obtained by students in taking TOEFL reading comprehension test.

4.3 Is there any significant correlation between students' cognitive test-taking strategies and their achievement in TOEFL reading comprehension?

To find out the correlation between cognitive test-taking strategies and TOEFL reading achievement, Pearson Product Moment was calculated in Table 3.

Table 3 Correlation between Cognitive Test-Taking Strategies and TOEFL Reading Achievement of English Education, English Literature, and Business English Students

\begin{tabular}{|c|c|c|}
\hline & & L.R.A \\
\hline \multirow{3}{*}{ C.T.S } & Pearson Correlation & $.822^{* *}$ \\
\hline & & .000 \\
\hline & $\mathrm{N}$ & 47 \\
\hline \multirow{3}{*}{ TOEFL.R.A } & Pearson Correlation & 1 \\
\hline & Sig. (2-tailed) & \\
\hline & $\mathrm{N}$ & 47 \\
\hline
\end{tabular}

As described in Table 3, there was significant and a positive correlation between cognitive test-taking strategies and TOEFL reading achievement. The both variables showed $\mathrm{r}=.822$ at $\mathrm{p}=.000$ in which categorized as positive and high. These data proved the hypothesis which $\mathrm{H} 0$ was rejected and $\mathrm{H} 1$ was accepted.

\section{Conclusion}

Based on findings and discussion in the previous chapter, the research results can be concluded that the most dominant cognitive test-taking strategy applied by students of English Department at the State University of Makassar is a comprehending strategy. Next, The TOEFL reading achievement of students of English Department is fair. It indicates that there is not a student who gets a reading 
score in the very poor category. Besides, there is a significant correlation between students' cognitive test-taking strategies and their achievement in TOEFL reading comprehension. The research results revealed that the correlation coefficient between cognitive test-taking strategies and TOEFL reading comprehension was $r$ $=.870^{* *}$ at $\mathrm{p}<0.05$ which was categorized as high. This study describes that cognitive test-taking strategies can assist students to obtain a better score in answering TOEFL reading comprehension test.

\section{Suggestion}

The researcher suggests that students should be trained to get comprehending strategies so that it can be easier for them to find the correct answer related to reading the passage. In addition, English teacher should combine other strategies to help students in taking TOEFL reading comprehension test. Due to the limitation of time, the next researcher should use another instrument in order to know the use of test-taking strategies applied by students.

\section{REFERENCES}

Alderson, J.C. 2000. Assessing Reading. Cambridge: Cambridge University Press. Bachman, L.F \& Palmer, A.S. 1996. Language Testing in Practice. Oxford: Oxford University Press.

Bachman, L.F. 1990. Fundamental Consideration in Language Testing. Oxford: Oxford University Press.

Cohen, A. D. \& Upton, T. 2006. Strategies in responding to the new TOEFL reading tasks [Monograph No. 33]. Princeton, NJ: ETS. (http://www.ets.org/Media/Research/pdf/RR-06-06.pdf).

Gay et al. 2006. Educational Research. New Jersey: Pearson Prentice Hall.

Ghafournia, N \& Afgari, A. 2013. The Interaction between Cognitive Test-Taking Strategies, Reading Ability, and Reading Comprehension Test Performance of Iranian EFL Learners. English Language Teaching, (Online), Vol.6, No.8 (http://www. ccsenet.org/elt, retrieved on September 11, 2013).

Grabe, W. 2005. Reading in a Second Language: Moving from Theory to Practice. United States of America (USA): Cambridge University Press.

Heinkel, E.2005.TOEFL Test Strategies $3^{\text {rd }}$ ed. Ciputat: Binarupa Aksara 
Hornby, A.S. 2000. Oxford Advanced Learner's Dictionary (6 ${ }^{\text {th }}$ Edition). Oxford: Oxford University Press.

Jabu,B. 2008. English Language Testing. Makassar: Badan Penerbit UNM

Jaiprayoon, R.V.K. 1999. An Assessment of the Effectiveness of Teaching TestTaking Strategies for Multiple-Choice English Reading Comprehension Tests (http://www.la.mahidol.ac.th, retrieved on February 3, 2014)

Mohammadi, M. P and Abidin, M. J. 2011. Test-taking Strategies, Schema Theory and Reading Comprehension Test Performance. International Journal of Humanities and Social Science, (Online) Vol. 1, No 18, p. 237 (http://www.ijhssnet.com/journal/index/586, retrieved November 16, 2013)

O’ Malley, J. M \& Chamot, A. U. 1990. Learning Strategies in Second Language Acquisition. United States of America (USA): Cambridge University Press.

Oxford, R. 1990. Language Learning Strategy: What Every Teacher Should Know. New York: Newbury House.

Phakiti, A.2006. Modelling Cognitive and Metacognitive Strategies and their Relationship to EFL Reading Test Performance. Melbourne Paper in Language Testing, (Online), Vol 11, No.1 (http://ltrc.unimelb.edu.au/mplt, retrieved on December 9, 2013).

Phillips, D. 2001. Longman Complete Course for the TOEFL Test (pdf). New York: Longman.

Purpura.J.E.1999. Learner Strategy Use and Performance on Language Tests: A Structural Equation Modelling Approach (Studies in Language Testing). Cambridge: University of Cambridge Local Examination Syndicate.

Stathopoulou, M \& Nikaki, D. 2009. Test-Taking Strategies in the KPG Reading Test: Instrument Construction \& Investigation Results. The Journal of Applied Linguistics (Online).Vol.25 (http://www/enl.auth.gr, retrieved on September 16, 2013)

Sugiyono. 2012. Metode Penelitian Kombinasi (Mixed Methods). Bandung: Alfabeta

Tankersley, K. 2003. The Threads of Reading. United States of America (USA): Association for Supervision and Curriculum Development Alexandria. 
Zhang, et al. 2013. English Test-Taking Strategy Use and Students' Test Performance. The Asian EFL Journal Quarterly (Online), Vol 13, No. 2 (http://www.asian-efl-journal.com, retrieved on September 11, 2013)

Zhare-ee, A. 2007. The Relationships between Cognitive and Metacognitive Strategy use and EFL Reading Achievement. Journal of applied Psychology (Online), Vo.2, No.5 (http://faculty.ksu.edu.sa, retrieved on March 9, 2014). 